\title{
Production, Predation and Food Niche Segregation in a Marine Shallow Soft-Bottom Community
}

\author{
Sverker Evans \\ Department of Zoology, Uppsala University, Box 561, S-751 22, Uppsala, Sweden
}

\begin{abstract}
A shallow soft bottom in Gullmar Fjord (Sweden) was investigated in order to determine the impact by epibenthic predators and possible competition for food between co-occurring shrimp and fish species. Large numbers of the shrimp Crangon crangon, juvenile plaice Pleuronectes platessa and sand goby Pomatoschistus minutus aggregated during summer in shallow areas and fed on benthic macro- and meiofauna. Predation impact was calculated using estimates of gross production efficiencies and production rates. In 1976 and 1977, yearly predation amounted to 12 and $17 \%$, respectively, of the total macro- and meiofauna production. The low exploitation rate of the benthic community contradicts the hypothesis that predation should be the major extrinsic determinant keeping population levels below the carrying capacity of the environment. Shallow soft bottoms provide an abundant food supply that will neither limit growth nor produce severe competition between the epibenthic predators, although their diets are almost identical. It is suggested that larger predators will control the abundance of epibenthic feeders such as shrimp, gobies and small flatfish inhabiting shallow water.
\end{abstract}

\section{INTRODUCTION}

Predation and competition are the most important biotic interactions influencing populations and communities. Species which simultaneously occupy the same habitat are likely to compete for resources available. The impact of predation differs, depending on the type of environment. In rocky intertidal communities, intense competition for space leads to the exclusion of inferior competitors (Connell 1961a, b, 1972, 1975; Dayton, 1971). Predation may reduce the intensity of competition for space by keeping competing species at low densities; therefore, diversity may be higher when predators are present (Connell, 1970; Dayton, 1971; Paine, 1974). In soft-bottom communities, on the other hand, the opportunity to burrow into the substrate makes it possible for interacting species to increase their spatial segregation, and space is not normally a limiting factor (Levinton and Bambach, 1975; Peterson, 1977: Peterson and Andre, 1980). Experiments demonstrate that soft-bottom communities from which epibenthic predators have been excluded usually support both a increased total density and an increased species richness. Reise (1977a, b, 1978) and Virnstein (1977) suggested that competition was lax within the infauna community. If so, the infauna populations inhabiting shallow soft-bottoms should not be resource limited but rather predator controlled. On the other hand, recent investigations in intertidal and subtidal environments have shown that epibenthic predators do not control infaunal composition or densities (Berge, 1980; Berge and Hesthagen, 1981).

This paper reports on a comprehensive investigation carried out in Kvarnbukten Bay (Sweden). Large numbers of shrimps and small fishes - the caridean decapod Crangon crangon L., juvenile plaice Pleuronectes platessa L., and the sand goby Pomatoschistus minutus (Pallas) - aggregate during the summer months in this shallow sandy area. At frequent intervals new cohorts of voraciously foraging shrimps and fishes invade this bay, feeding on the benthic macro- and meiofauna. During the warm season shallow soft bottoms become tightly packed with predaceous epibenthic feeders compared to bordering deeper waters (Evans and Tallmark, in prep.).

This paper focuses on documenting the predation impact on the benthic infauna in a marine shallow softbottom area, where such data are almost completely missing, and on examining whether competition for food exists between co-dominant epibenthic predators. 


\section{AREA DESCRIPTION}

The investigation area, Kvarnbukten Bay, is Iocated at the entrance of the Gullmar Fjord (N 58 15 ; E 1 1 ${ }^{\circ} 28$ ) on the Swedish west coast. It comprises a shallow sandy bay ( $\leqq 1 \mathrm{~m}$ depth) surrounded by rocky shores. The bottom substrate is dominated by fine and very fine sand. The area is moderately exposect, and the tidal influence is nearly nil (Evans and Tallmark. 1975).

\section{Bottom Fauna}

\section{Sampling Design and Treatment}

From 1976 to 1977 a sampling survey was performed in Kvarnbukten Bay in order to assess the abundance, biomass and production of the benthic infauna constituting the main food resource for the predaceous epifauna. The bay was stratified according to depth and substrate composition (Evans and Tallmark, 1976, 1977). Random sampling was carried out in the different strata within the border lines of HWL and $1 \mathrm{~m}$ depth. The sampling program was run 3 times $\mathrm{yr}^{-1}$ during 1976 and 1977 for macrofauna and 3 times during 1976 for meiofauna, comprising a total number of 744 macrofauna and 372 maiofauna samples. For the macrofauna, a core with $38.5 \mathrm{~cm}^{2}$ sampling area was pushed down into the sediment to a depth of $15 \mathrm{~cm}$.

In order to assess the vertical distribution of the infauna, the upper $5 \mathrm{~cm}$ of the sediment was immediately separated from the underlaying 5 to $15 \mathrm{~cm}$ fraction. The whole sediment samples were preserved in $10 \%$ buffered formaldehyd solution. In the laboratory the sediment was sieved through a metal gauze of $0.5 \mathrm{~mm}$ mesh size and the sieve residues were sorted under a stereo microscope. Meiofauna samples were collected with a $1.77 \mathrm{~cm}^{2}$ core which penetrated the sediment to a depth of $2 \mathrm{~cm}$. The samples were preserved in $4 \%$ buffered formaldehyd solution and were sorted under a stereo microscope.

\section{Faunal Data and Statistics}

The macrofauna was identified to species (in a few cases family) and counted. Dry weights of the individual formalin-preserved samples were determined in order to estimate deviation in biomass. Standard dry weights for dominant macrofauna taxa were obtained by weighing batches of 10 to 50 formalin-preserved specimens collected during summer after drying at $60{ }^{\circ} \mathrm{C}$ to constant weight.

The permanent meiofauna included the following dominant groups: nematodes, copepods, ostracods and foraminiferans. As a first approximation the groups were treated summarily without species identification. Weight determinations were made on the basis of volume measurements. The volume multiplied by specific gravity gave the wet weights. For nematodes a sample of 100 specimens was randomly collected. Their volumes were determined assuming a cylindric shape and correcting according to Andrassý's (1956) formula. Individual mean wet weight was calculated assuming a density of 1.13 (Wieser, 1960). Weights of ostracods and harpacticoids were determined in a similar way, assuming an ellipsoid shape and a density of 1. A mean individual value of $1.5 \mu \mathrm{g}$ was used to calculate the biomass of foraminifers (Olsson, 1975). Conversion from mean wet to dry weights was made using coefficients obtained from Wieser (1960). Most of the temporary meiofauna species, such as young polychaetes and newly settled bivalve spat, were retained in the $500 \mu \mathrm{m}$ mesh and were therefore added to the macrofauna.

Abundance and biomass means and their standard errors for the macro- and meiofauna were calculated for the different strata and the weighted means and their standard errors were calculated according to Snedecor and Cochran (1967).

\section{Production Calculations}

Standard weights and densities of dominant macroand meiofauna taxa, together with calculated production/biomass ratios, were used to estimate the annual production of the benthic community in Kvarnbukten Bay. The relationship between adult body mass and annual $P / B$ ratio was investigated by Banse and Mosher (1980) for a number of invertebrates. Body mass (M) upon reaching maturity was shown to be a precise scaling factor of the annual $\mathrm{P} / \mathrm{B}$, the ratio declining with increasing body mass according to

$$
\mathrm{P} / \mathrm{B}=0.65 \mathrm{M}^{-0.37} \mathrm{yr}^{-1}
$$

which were considered adequate for estimating the annual macrofauna production.

For very small metazoans such as those making up the permanent meiofauna, the $\mathrm{P} / \mathrm{B}$ ratios calculated from Banse and Mosher (1980) however become considerably overestimated. For the permanent meiofauna, production was calculated by using $\mathrm{P} / \mathrm{B}$ ratios of 9 for nematodes (Gerlach, 1971), 15 for harpacticoids (Lasker et al., 1970; Warwick et al., 1979), 4 for ostracods (Heip and Vranken, 1977) and 1 for foraminiferans (Gerlach, 1971). 


\section{Epifauna Food Composition}

The stomach contents of brown shrimp, juvenile plaice and sand goby collected in Kvarnbukten Bay from 1976 to 1977 (Evans and Tallmark, 1979) were used to determine the seasonal variation of the diet of each species. The predators were classified in length groups of $10 \mathrm{~mm}$. If possible, 30 individuals of each size class were examined on every sampling occasion. A total of 1876 shrimp, 6810 -group plaice and 674 sand gobies from 18 sampling occasions were examined. The number of individuals of each prey species was recorded for all stomachs within every size class, and the total sum of the different prey species was expressed as a percentage proportion of the total number of individuals of all food categories. A standard food composition was thus created for the specific size class and sampling occassion. Detritus, which does not occur in discrete units, was omitted in the stomach analyses.

\section{Predation Impact}

In order to calculate the annual impact of predation on a community, it is necessary to know the gross production efficiency - annual production to annual consumption - of the predator. From the back calculations of the amount of food required to feed the epibenthic predators, a minimum value of prey production was obtained. This value was compared with the production calculations based on benthic biomass measurements and assessed $\mathrm{P} / \mathrm{B}$ ratios in order to estimate the share of the infauna production.

\section{Niche Width and Niche Overlap}

The diet data were analyzed in terms of niche width and degree of food-resource overlap between the 3 species. Niche width $B=\left(\Sigma p_{i}{ }^{2}\right)^{-1}$ (Levins, 1968) was calculated from the proportions $p_{1}$ of prey among the epifauna food categories. $p_{i}$ is the proportional use of a food category $i$ relative to the other categories. The value of $B$ varies from 1 to $n$, where $n=$ number of food categories. If all prey items are from one category, then $\mathrm{B}=1$. If all prey categories are equally common in the diet (all $\mathrm{p}_{\mathrm{i}}=\frac{1}{\mathrm{n}}$ ), then $\mathrm{B}=\mathrm{n}$. To compare values of $\mathrm{B}$ with different $\mathrm{n}$ values, normalization is required, especially when $n$ is small. Niche widths were standardized for comparison to fractions $(0-1)$ of the maximum possible niche width by the formula

$$
\mathrm{B}_{\mathrm{s}}=\frac{\mathrm{B}-1}{\mathrm{n}-1}
$$

The formula of McArthur and Levins (1967) was used to calculate food niche overlap

and

$$
\begin{aligned}
& \alpha_{2 \mathrm{j}}=\frac{\Sigma \mathrm{p}_{\mathrm{1}} \mathrm{p}_{\mathrm{J}}}{\sum \mathrm{p}_{\mathrm{i}}{ }^{2}} \\
& \alpha_{\mathrm{jl}}=\frac{\Sigma \mathrm{p}_{1} \mathrm{p}_{3}}{\sum \mathrm{p}_{\mathrm{J}}^{2}}
\end{aligned}
$$

where $\alpha_{1 j}=$ overlap of species $j$ on species $i$ and vice versa. The value of $\alpha$ varies from 0 with no overlap to 1 for complete overlap. The average value of the estimates of $\alpha$ is identical to the overlap measure of Horn (1966).

\section{RESULTS}

\section{Infaunal Community Structure}

The weighted mean abundance and biomass values of the benthic macrofauna are displayed in Table 1. The 10 most abundant species accounted for 94 to $99 \%$ of the total number, and all year round the community was numerically dominated by oligochaetes and polychaetes. Some $65 \%$ of the species occurred in less than $10 \%$ of the samples. The biomass values for the macrofauna ranged from 2.4 to $6.2 \mathrm{~g} \mathrm{~m}^{-2}$ dry weight. Polychaetes comprised the bulk of the biomass, far outranking all other groups. Over $90 \%$ of the macrofauna were found in the upper $5 \mathrm{~cm}$ of the sediment. As a result of recruitment to the populations during the warm season together with rapid growth, both density and biomass values showed a distinct increase during the year. In 1976 the macrofauna biomass increased from 63 to $161 \%$ of the yearly average; the corresponding values for 1977 was 19 to $137 \%$.

In the meiofauna samples, nematodes were clearly the dominant organisms; they were present in large numbers in all strata (Table 2). Copepods were second in overall abundance, followed by ostracods and foraminiferans. The remaining fauna consisted of softbodied forms which were difficult to identify after preservation, e.g. hydroids, turbellarians and gastrotrichs. Total meiofauna biomass ranged from 0.3 to $0.8 \mathrm{~g} \mathrm{~m}^{-2}$ dry weight which contributed 10 to $16 \%$ to the total benthic biomass. Since all meiofauna groups were not included in the calculations, and since the sampling device penetrated to a depth of only $2 \mathrm{~cm}$, meiofauna biomass values are minimum values. In conformity with the macrofauna, meiofauna biomass increased during 1976 from 49 to $145 \%$ of the yearly mean value.

Stereotyped standard weights of dominant macroand meiofauna taxa and predicted $\mathrm{P} / \mathrm{B}$ ratios were used with the aim to calculate the annual production of the 
Table 1. Weighted mean abundance $\left(\mathrm{m}^{-2} \pm\right.$ S.E.) and frequency (\%) of the 10 dominant benthic macrofauna species in Kvarnbukten Bay, Sweden. Abundance and biomass ( $\mathrm{g} \mathrm{m}^{-2}$ dry wt \pm S.E.) values refer to the total benthic community

\begin{tabular}{|c|c|c|c|c|c|c|c|c|c|c|c|c|}
\hline & \multicolumn{6}{|c|}{1976} & \multicolumn{6}{|c|}{1977} \\
\hline & \multicolumn{2}{|l|}{ Apr } & \multicolumn{2}{|l|}{ Jun } & \multicolumn{2}{|l|}{ Nov } & \multicolumn{2}{|l|}{ May } & \multicolumn{2}{|l|}{ Jul } & \multicolumn{2}{|l|}{ Oct } \\
\hline & & $\%$ & & $\%$ & & $\%$ & & $\%$ & & $\%$ & & $\%$ \\
\hline Eteone longa & & & $95 \pm 47$ & 18 & & & $102 \pm 37$ & 5 & $900 \pm 213$ & 54 & $207 \pm 45$ & 46 \\
\hline Microphtalmus sp. & $16 \pm 11$ & 1 & & & & & & & & & & \\
\hline Nereis virens & $58 \pm 38$ & 8 & & & $141 \pm 39$ & 29 & $45 \pm 20$ & 11 & & & $132 \pm 37$ & 27 \\
\hline N. diversicolor & & & $34 \pm 22$ & 11 & & & & & & & & \\
\hline Nereis sp. & $38 \pm 18$ & 24 & $2837 \pm 444$ & 89 & $142 \pm 48$ & 24 & $90 \pm 35$ & 30 & $896 \pm 167$ & 72 & $218 \pm 69$ & 33 \\
\hline Scoloplos armiger & $87 \pm 9$ & 22 & $826 \pm 254$ & 43 & $136 \pm 40$ & 37 & $218 \pm 54$ & 26 & $403 \pm 189$ & 31 & $174 \pm 50$ & 39 \\
\hline Spio filicornis & $227 \pm 63$ & 42 & $59 \pm 23$ & 17 & $1463 \pm 264$ & 61 & $40 \pm 12$ & 32 & & & $374 \pm 78$ & 44 \\
\hline Pygospio elegans & $604 \pm 242$ & 48 & $2105 \pm 593$ & 60 & $1102 \pm 261$ & 63 & $702 \pm 270$ & 45 & $1558 \pm 600$ & 63 & $2649 \pm 1337$ & 68 \\
\hline Malacoceros tetracerus & $15 \pm 13$ & 3 & & & & & & & & & & \\
\hline Capitella capitata & $156 \pm 47$ & 35 & $330 \pm 267$ & 15 & $640 \pm 181$ & 40 & $223 \pm 60$ & 35 & $513 \pm 156$ & 24 & $1341 \pm 335$ & 60 \\
\hline Oligochaeta & $1561 \pm 294$ & 75 & $1442 \pm 368$ & 72 & $2005 \pm 482$ & 78 & $1305 \pm 280$ & 63 & $1166 \pm 377$ & 65 & $1269 \pm 383$ & 74 \\
\hline Mya arenaria & & & & & & & & & $43 \pm 21$ & 12 & & \\
\hline Cerastoderma edule & & & & & & & $17 \pm 8$ & 2 & $63 \pm 25$ & 13 & & \\
\hline Tellina tenuis & & & $17 \pm 9$ & 7 & $28 \pm 12$ & 6 & & & & & & \\
\hline Hydrobia sp. & & & & & $161 \pm 52$ & 18 & & & $789 \pm 351$ & 29 & $1130 \pm 256$ & 67 \\
\hline Corophium volutator & $55 \pm 16$ & 22 & $157 \pm 37$ & 19 & $232 \pm 82$ & 12 & $111 \pm 26$ & 25 & $969 \pm 226$ & 44 & $499 \pm 125$ & 33 \\
\hline \multicolumn{13}{|l|}{ Total abundance } \\
\hline $0-5 \mathrm{~cm}$ & $2633 \pm 475$ & & $7230 \pm 942$ & & $3210 \pm 525$ & & $2566 \pm 567$ & & $6174 \pm 1264$ & & $7169 \pm 1676$ & \\
\hline $5-15 \mathrm{~cm}$ & $242 \pm 90$ & & $767 \pm 224$ & & $2953 \pm 493$ & & $339 \pm 107$ & & $1350 \pm 310$ & & $1325 \pm 358$ & \\
\hline $0-15 \mathrm{~cm}$ & $2875 \pm 513$ & & $7997 \pm 1019$ & & $6163 \pm 911$ & & $2905 \pm 598$ & & $7524 \pm 1204$ & & $8494 \pm 1809$ & \\
\hline \multicolumn{13}{|l|}{ Total biomass } \\
\hline $0-5 \mathrm{~cm}$ & $1.22 \pm 0.34$ & & $1.87 \pm 0.45$ & & $2.77 \pm 0.60$ & & $2.08 \pm 0.30$ & & $3.16 \pm 0.86$ & & $3.05 \pm 0.50$ & \\
\hline $5-15 \mathrm{~cm}$ & $1.77 \pm 0.61$ & & $1.01 \pm 0.58$ & & $3.31 \pm 1.66$ & & $1.03 \pm 0.88$ & & $1.02 \pm 0.72$ & & $3.10 \pm 1.40$ & \\
\hline $0-15 \mathrm{~cm}$ & $2.39 \pm 0.78$ & & $2.88 \pm 0.88$ & & $6.08 \pm 1.19$ & & $3.11 \pm 0.86$ & & $4.18 \pm 1.37$ & & $6.15 \pm 1.48$ & \\
\hline
\end{tabular}

Table 2. Weighted mean abundance $\left(\mathrm{m}^{-2} \pm\right.$ S.E.) and biomass $\left(\mathrm{g} \mathrm{m}^{-2}\right.$ dry wt \pm S.E.) of benthic meiofauna in Kvarmbukten Bay 1976

\begin{tabular}{|c|c|c|c|}
\hline & April & June & Nov \\
\hline \multicolumn{4}{|l|}{ ABUNDANCE } \\
\hline Nematoda & $5.12 \cdot 10^{5} \pm 7.18 \cdot 10^{4}$ & $7.86 \cdot 10^{5} \pm 7.95 \cdot 10^{4}$ & $1.08 \cdot 10^{6} \pm 1.19 \cdot 10^{5}$ \\
\hline Harpacticoida & $1.75 \cdot 10^{4} \pm 4.1 \quad 10^{3}$ & $2.16 \cdot 10^{5} \pm 1.77 \cdot 10^{4}$ & $3.2810^{5} \pm 4.3410^{4}$ \\
\hline Ostracoda & $7.7 \cdot 10^{3} \pm 1.8 \cdot 10^{3}$ & $3.21 \cdot 10^{4} \pm 6.9 \quad 10^{3}$ & $4.48 \cdot 10^{4} \pm 7.5 \cdot 10^{3}$ \\
\hline Foraminifera & $3.62 \cdot 10^{4} \pm 8.4 \cdot 10^{3}$ & $1.41 \quad 10^{4} \pm 4.2 \quad 10^{3}$ & $7.0 \quad 10^{3} \pm 2.3 \cdot 10^{3}$ \\
\hline Total & $5.73 \cdot 10^{5} \pm 2.37 \cdot 10^{4}$ & $1.05 \cdot 10^{6} \pm 8.38 \cdot 10^{4}$ & $1.46 \cdot 10^{6} \pm 7.04 \cdot 10^{4}$ \\
\hline \multicolumn{4}{|l|}{ BIOMASS } \\
\hline Nematoda & $1.8 \cdot 10^{-1} \pm 3 \cdot 10^{-2}$ & $2.8 \cdot 10^{-1} \pm 3 \cdot 10^{-2}$ & $3.8 \cdot 10^{-1} \pm 4 \cdot 10^{-2}$ \\
\hline Harpacticoida & $1 \cdot 10^{-2} \pm 3 \cdot 10^{-3}$ & $1.6 \cdot 10^{-1} \pm 1 \cdot 10^{-2}$ & $2.4 \cdot 10^{-1} \pm 3 \cdot 10^{-2}$ \\
\hline Ostracoda & $2 \cdot 10^{-2} \pm 1 \cdot 10^{-2}$ & $1.0 \cdot 10^{-1} \pm 2 \cdot 10^{-2}$ & $1.4 \cdot 10^{-1} \pm 210^{-2}$ \\
\hline Foraminifera & $5 \quad 10^{-2} \pm 1 \quad 10^{-2}$ & $2 \quad 10^{-2} \pm 1 \cdot 10^{-2}$ & $1 \cdot 10^{-2} \pm 3 \cdot 10^{-3}$ \\
\hline Total & $2.610^{-1} \pm 1 \quad 10^{-2}$ & $5.6 \cdot 10^{-1} \pm 1 \cdot 10^{-2}$ & $7.7 \quad 10^{-1} \pm 1 \quad 10^{-2}$ \\
\hline
\end{tabular}

benthic community. In order to obtain a general $\mathrm{P} / \mathrm{B}$ value for the whole infauna community, the $P / B$ ratios of the different species were weighted in proportion to their corresponding biomasses (Table 3). A mean macrofauna standing stock of 3.8 and $4.5 \mathrm{~g} \mathrm{~m}^{-2}$ for 1976 and 1977 , respectively, gave corresponding production values of 26.5 and $20.7 \mathrm{~g} \mathrm{~m}^{-2} \mathrm{yr}^{-1}$. For the meiofauna, a standing stock during 1976 of $0.5 \mathrm{~g} \mathrm{~m}^{-2}$ gave $5.0 \mathrm{~g} \mathrm{~m}^{-2} \mathrm{yr}^{-1}$ as an average production rate.

\section{Epifauna Food Composition}

The standard food composition of prey items eaten by shrimp, juvenile plaice and sand gobies for different sizes and seasons is shown in Table 4. Here only the values obtained for June to August 1977 are shown. Generally an increased variation in food particle size was observed in all three species during growth. Brown shrimp $\leqslant 20 \mathrm{~mm}$ predominantly fed on 
Table 3. Calculated $\mathrm{P} / \mathrm{B}$ ratios for the benthic community. Weighted mean values

\begin{tabular}{|c|c|c|c|c|c|c|c|}
\hline \multicolumn{4}{|c|}{ MEIOFAUNA } & \multicolumn{4}{|c|}{ MACROFAUNA } \\
\hline & $\mathrm{g} \mathrm{m}^{-2}$ & $\mathrm{~g} \mathrm{~m}^{-2} \mathrm{yr}^{-1}$ & $y^{-1}$ & & $\mathrm{~g} \mathrm{~m}^{-2}$ & $\mathrm{~g} \mathrm{~m}^{-2} \mathrm{yr}^{-1}$ & $\mathrm{yr}^{-1}$ \\
\hline 1976 & B & $P$ & $\mathrm{P} / \mathrm{B}$ & 1976 & B & $P$ & $\mathrm{P} / \mathrm{B}$ \\
\hline April & 0.3 & 1.9 & 7.3 & April & 2.4 & 17.8 & 7.4 \\
\hline June & 0.6 & 5.3 & 9.5 & June & 2.9 & 19.3 & 6.7 \\
\hline Nov & 0.8 & 7.6 & 9.9 & Nov & 6.1 & 41.9 & 6.9 \\
\hline \multirow[t]{6}{*}{$\overrightarrow{\mathrm{x}}$} & 0.5 & 5.0 & 8.9 & $\bar{x}$ & 3.8 & 26.5 & 7.0 \\
\hline & & & & 1977 & & & \\
\hline & & & & May & 3.1 & 14.8 & 4.8 \\
\hline & & & & July & 4.2 & 8.8 & 2.1 \\
\hline & & & & Oct & 6.2 & 42.9 & 7.0 \\
\hline & & & & $\overline{\mathrm{x}}$ & 4.5 & 20.7 & 4.6 \\
\hline
\end{tabular}

Table 4. Standard composition of stomach contents of brown shrimp, plaice and sand goby from June to August 1977

\begin{tabular}{|c|c|c|c|c|c|c|c|c|c|c|c|c|c|c|c|}
\hline & & & Jun & & & & & Jul & & & & & Aug & & \\
\hline CRANGON & $<20$ & $21-30$ & $31-40$ & $41-50$ & $>50$ & $<20$ & $21-30$ & $31-40$ & $41-50$ & $>50$ & $<20$ & $21-30$ & $31-40$ & $41-50$ & $>50$ \\
\hline Meiofauna & 74 & 29 & 6 & 8 & 14 & 78 & 1 & 33 & & 4 & 90 & 23 & 15 & 2 & \\
\hline Polychaeta & 6 & 5 & 55 & 36 & 49 & 20 & 44 & 16 & 55 & 2 & 1 & 11 & 2 & 66 & 48 \\
\hline Mollusca & 16 & 30 & 8 & 6 & 2 & 2 & 50 & 30 & & 35 & & 40 & 36 & 20 & \\
\hline Crustacea & 2 & 26 & 31 & 56 & 35 & & 5 & 19 & 45 & 59 & 1 & 26 & 47 & 12 & 52 \\
\hline Others & & 10 & & & & & & 2 & & & 8 & & & & \\
\hline n stomachs & 30 & 30 & 30 & 30 & 8 & 30 & 30 & 30 & 30 & 22 & 30 & 30 & 30 & 30 & 19 \\
\hline n prey org. & 109 & 160 & 88 & 95 & 13 & 330 & 95 & 47 & 68 & 35 & 171 & 30 & 55 & 23 & 42 \\
\hline PLAICE & $<20$ & $21-30$ & $31-40$ & $41-50$ & $>50$ & $<20$ & $21-30$ & $31-40$ & $41-50$ & $>50$ & $<20$ & $21-30$ & $31-40$ & $41-50$ & $>50$ \\
\hline Meiofauna & 98 & 83 & 25 & 25 & & & 87 & 48 & 15 & & & & 49 & 13 & 4 \\
\hline Polychaeta & & 11 & 22 & 41 & & & 2 & 14 & 40 & 67 & & & & 48 & \\
\hline Mollusca & 2 & 6 & 44 & 31 & & & 9 & 18 & 11 & & & & 13 & 21 & 13 \\
\hline Crustacea & & & 7 & 3 & & & 2 & 19 & 34 & 22 & & & 12 & 15 & 24 \\
\hline Others & & & 2 & & & & & 1 & & 6 & & & & 3 & 4 \\
\hline n stomachs & 30 & 30 & 30 & 8 & & & 30 & 30 & 30 & 30 & & & 30 & 30 & 21 \\
\hline n prey org. & 890 & 396 & 107 & 74 & & & 3725 & 641 & 163 & 98 & & & 237 & 318 & 88 \\
\hline SAND GOBY & & & & & & $<20$ & $21-30$ & $31-40$ & $41-50$ & $>50$ & $<20$ & $21-30$ & $31-40$ & $41-50$ & $>50$ \\
\hline Meiofauna & & & & & & 10 & 11 & & & & & 20 & 7 & & \\
\hline Calanoid Copepoda & & & & & & 90 & 86 & 36 & & & & 45 & 65 & 77 & 39 \\
\hline Polychaeta & & & & & & & 3 & 5 & & & & 13 & 16 & 1 & 13 \\
\hline Crustacea & & & & & & & & 57 & & & & 18 & 12 & 22 & 39 \\
\hline Others & & & & & & & & 2 & & & & 4 & & & 5 \\
\hline n stomachs & & & & & & 9 & 14 & 11 & & & & 30 & 30 & 30 & 17 \\
\hline n prey org. & & & & & & 177 & 318 & 19 & & & & 446 & 682 & 90 & 28 \\
\hline
\end{tabular}

meiofauna. Larger individuals preyed on crustaceans and annelids, but meiofauna also appeared in their stomachs.

Cannibalism is a very common feature, and newly settled plaice are susceptible to predation by the shrimp. This agrees with the observations made by Edwards and Steele (1968). In early May newly metamorphosed plaice larvae mostly preyed on harpacticoids. With increasing size they switched from meiofauna to spionid polychaetes and newly settled bivalves. Contrary to the other 2 species, which entirely fed on benthic organisms, the sand goby ate a lot of calanoid copepods. Other mobile organisms like species of Crangon and Corophium also made up a larger part of its total food spectrum.

\section{Epifauna Predation Impact}

Estimates of gross production efficiencies were obtained from the literature (Table 5), and were used in connection with production figures for the epifauna 
Table 5. Calculated predation impact by epifauna

\begin{tabular}{|c|c|c|c|c|c|c|}
\hline \multirow[t]{2}{*}{ Species } & \multirow[t]{2}{*}{$\begin{array}{c}\% \\
\text { Gross prod eff. }\end{array}$} & \multirow[t]{2}{*}{ Ref. } & \multicolumn{2}{|c|}{$\begin{array}{l}\mathrm{g} \mathrm{m}^{-2} \mathrm{yr}^{-1} \\
\text { Production }\end{array}$} & \multicolumn{2}{|c|}{$\begin{array}{c}\mathrm{g} \mathrm{m}^{-2} \mathrm{yr}^{-2} \\
\text { Consumption rates }\end{array}$} \\
\hline & & & 1976 & 1977 & 1976 & 1977 \\
\hline Crangon & 39 & Meixner $(1968)^{\circ}$ & 1.32 & 1.47 & 3.38 & 3.77 \\
\hline Juv, plaice & 20 & $\begin{array}{l}\text { Colman (1970) } \\
\text { Bregnballe (1961) } \\
\text { Müller (1972) }\end{array}$ & 0.16 & 0.28 & 0.79 & 1.40 \\
\hline Sand goby & & Healy (1972) & 0.09 & 0.17 & $\frac{0.37}{4.55}$ & $\frac{0.38}{5.55}$ \\
\hline $\begin{array}{l}\text { - Calculated as } \\
\text { - Ingestion rate }\end{array}$ & $\begin{array}{l}\text { rage from } 32 \% \\
\text { als } 3 \% \text { of body }\end{array}$ & $\begin{array}{l}\text { ales) and } 45 \% \text { (fe } \\
\text { eight per day }\end{array}$ & & & & \\
\hline
\end{tabular}
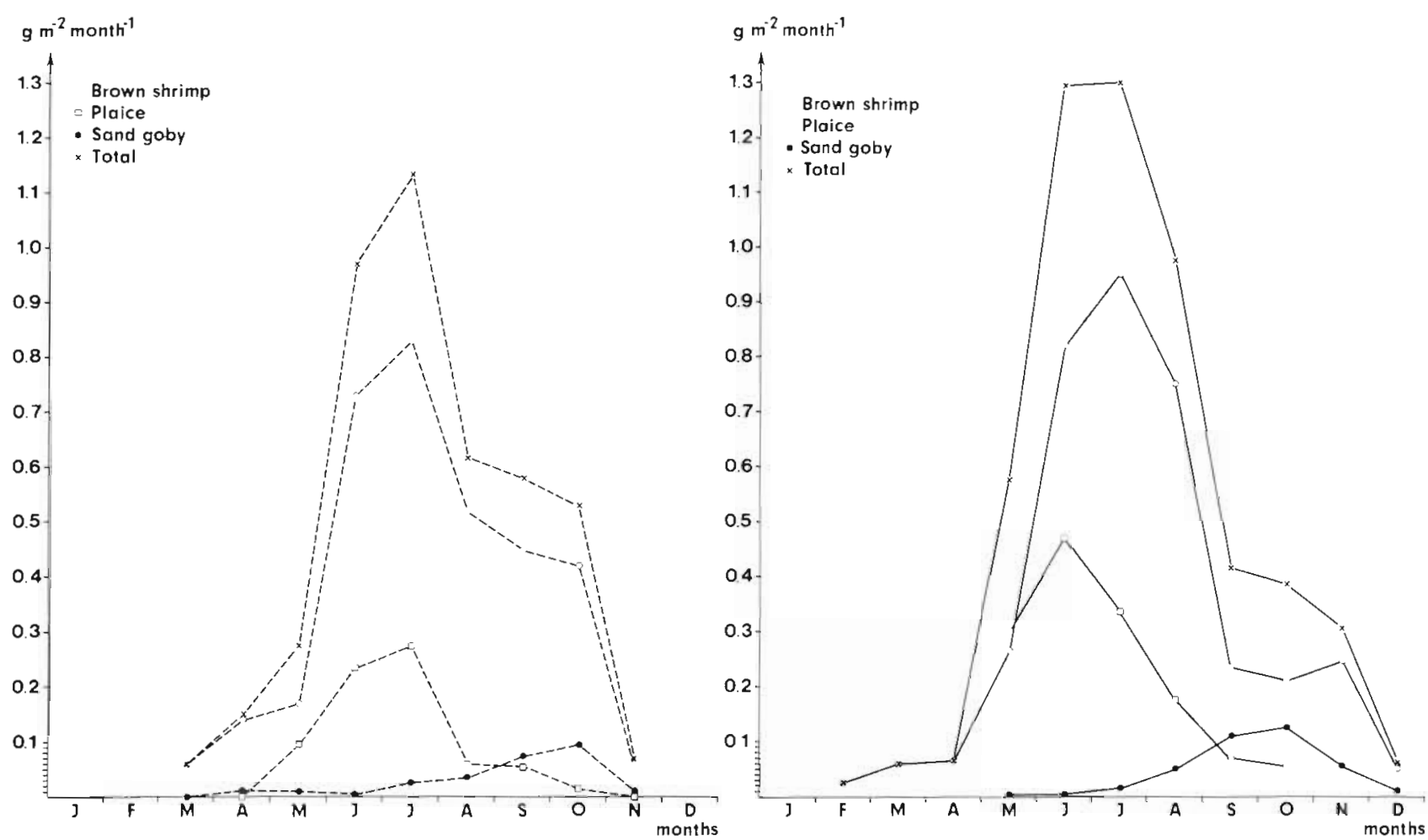

Fig. 1. Seasonal predation impact of epibenthic predators, calculated as $\mathrm{g} \mathrm{m}^{-2} \mathrm{mo}^{-1}$ dry weight removed from the benthic community. - - 1976; 1977

in Kvarnbukten Bay (Evans and Tallmark, 1979) to calculate the share of the infauna production required to support the epifauna (Table 5). The predation impact on the benthic infauna amounted to 3.8 and $4.3 \mathrm{~g} \mathrm{~m}^{-2} \mathrm{yr}^{-1}$, i.e. 12 and $17 \%$ of the total calculated macro- and meiofauna production for 1976 and 1977 , respectively. Besides, 0.8 and $1.3 \mathrm{~g} \mathrm{~m}^{-2} \mathrm{yr}^{-1}$, respectively, of the yearly food intake consisted of Crangon crangon (Evans, in prep.). Using epifaunal production data obtained on monthly basis (Evans Tallmark, 1979), and gross production efficiencies (Table 5), it was possible to construct the seasonal predation impact curves for the years 1976 and 1977 in Kvarnbukten Bay (Fig. 1).

\section{Niche Widths and Overlaps}

The number of species sharing a limited resource that can coexist in a given community depends on the niche width of the different species and on the degree to which their niches overlap. Fig. 2 shows niche 

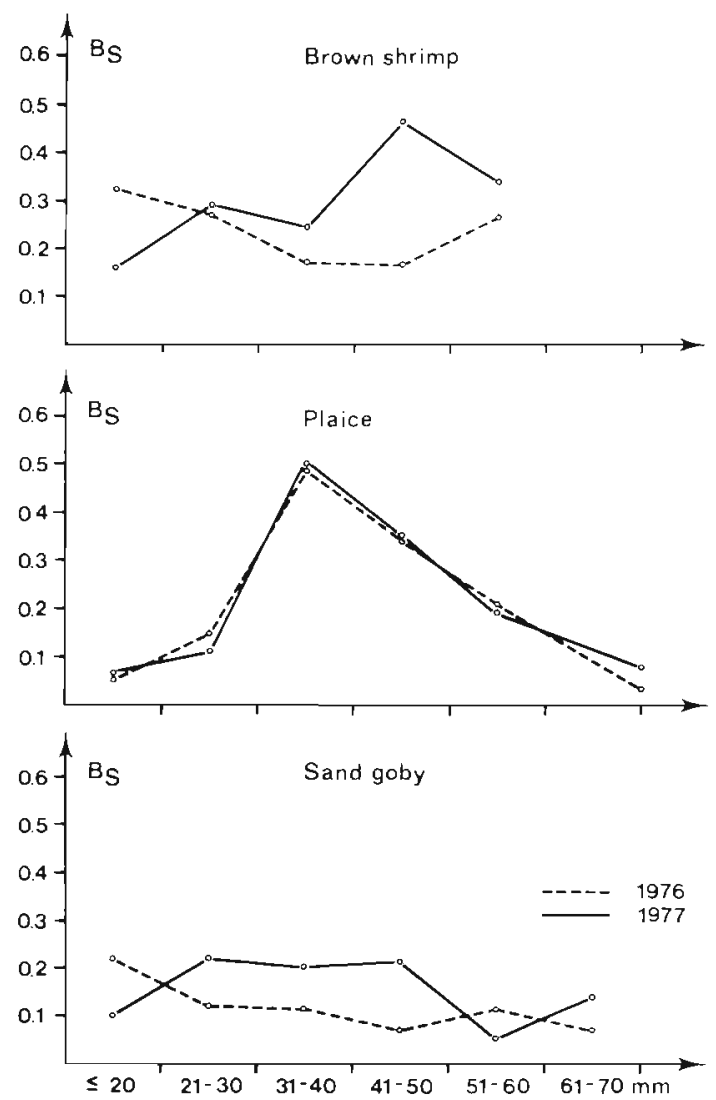

Fig. 2. Standardized niche width of different size groups of brown shrimp, plaice and sand goby

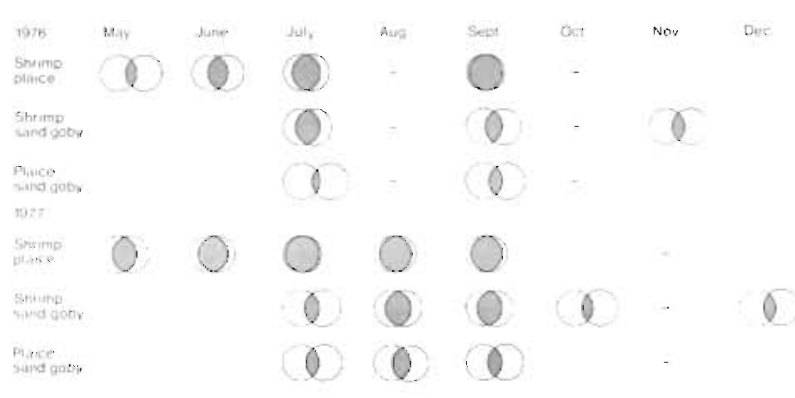

Fig. 3. Average overlap $\alpha(\%)$ for brown shrimp, plaice and sand goby, 1976 to 1977

widths with respect to food for different size groups of epibenthic predators, calculated as yearly average values. For plaice, niche width reaches a maximum value at a size of 30 to $40 \mathrm{~mm}$, indicating a change from a rather uniform to a more diverse food choice. With further increase in length, the niche width decreases, probably due to reduction of the number of prey species of suitable size. Overlap is the common utilization of the same resources by 2 or more organisms, regardless of resource abundance. Table 6 shows the overlaps $\alpha_{1 j}$, calculated on a monthly basis. The niche overlap evaluation clearly shows a change for the species pair shrimp-plaice from distinctly separated food niches in spring to widely overlapping ones in late summer. The average value of $\alpha$ is identical to the overlap measure $\bar{C}_{\lambda}$ of Horn (1966). Fig. 3 illustrates

Table 6. Food resource overlap between brown shrimp, juvenile plaice and sand goby

\begin{tabular}{|c|c|c|c|c|c|}
\hline \multicolumn{6}{|c|}{ Brown shrimp (i) - plaice (j) } \\
\hline 1976 & May & Jun & Jul & Sept & \multirow{3}{*}{ overlap of $j$ on $l$} \\
\hline ij & 0.14 & 0.39 & 0.46 & 0.99 & \\
\hline ji & 0.06 & 0.42 & 0.76 & 0.92 & \\
\hline 1977 & May & Jun & Jul & Aug & Sept \\
\hline ij & 0.58 & 0.91 & 1.00 & 0.84 & 0.80 \\
\hline ji & 0.28 & 0.58 & 0.90 & 0.85 & 0.83 \\
\hline \multicolumn{6}{|c|}{ Brown shrimp (i) - sand goby (j) } \\
\hline 1976 & Jul & Sep & Nov & & \\
\hline ij & 0.46 & 0.36 & 0.22 & & \\
\hline ji & 0.40 & 0.30 & 0.14 & & \\
\hline 1977 & Jul & Aug & Sep & Oct & Dec \\
\hline ij & 0.32 & 0.52 & 0.53 & 0.15 & 0.19 \\
\hline ji & 0.15 & 0.49 & 0.46 & 0.06 & 0.08 \\
\hline \multicolumn{6}{|c|}{ Plaice (i) - sand goby (j) } \\
\hline 1976 & Jul & Sep & & & \\
\hline ij & 0.05 & 0.23 & & & \\
\hline ji & 0.03 & 0.20 & & & \\
\hline 1977 & Jul & Aug & Sep & & \\
\hline ij & 0.25 & 0.37 & 0.26 & & \\
\hline ji & 0.13 & 0.35 & 0.22 & & \\
\hline
\end{tabular}


the overlap $\bar{C}_{\lambda}$ for the different months as partly overlapping circles. A dietary overlap of $>90 \%$ for shrimp-plaice in September 1976 indicates their similar food preferences.

\section{DISCUSSION}

Sampling difficulties and unknown generation times frequently reduce the accuracy of estimates of benthic biomass and yearly production. Superimposed on these problems is a complex net of predator-prey interactions within the benthic community. There is, for example, little information available about the influence of predaceous infaunal invertebrates on benthic production. It is therefore unavoidable to make some approximations. The stereotyped individual weights recorded from animals during summer were used throughout the year in order to determine the biomass of the different species, and the fluctuations of mean size caused by recruitment and growth were disregarded. The biomass values for the total macrofauna community ranged from 2.4 to $6.1 \mathrm{~g} \mathrm{~m}^{-2}$ dry weight which is close to the values obtained for moderately exposed or sheltered Scottish beaches (McIntyre, 1970).

Due to the prevalence of small macrofauna species, e.g. spionid plychaetes, the use of the general equation by Banse and Mosher (1980) produced high P/B ratios. Accordingly, the predicted production rates for the benthic community became very high compared to other investigations from similar habitats (Buchanan and Warwick, 1974; Burke and Mann, 1974; Warwick and Price, 1975). However, the earlier calculations of $\mathrm{P} / \mathrm{B}$ ratios of the benthic community usually have been derived from a number of large, slowly growing species, which will give $\mathrm{P} / \mathrm{B}$ ratios close to one. The dominance of small, short-lived annelids in Kvarnbukten Bay will justify the high yearly production rates obtained.

Assessments of the predation pressure exerted by shallow-water populations of fish and invertebrate species are rare, especially synoptic studies of predator and prey abundances and feeding preferences. Kuipers (1977) investigated the food intake by juvenile plaice in the Dutch Wadden Sea, and Beukema (1974, 1976) reported results on the seasonal changes of the benthic macrofauna biomass in the same area. In the Wadden sea, the total food intake by 0 -group plaice amounted to $0.25 \mathrm{~g} \mathrm{~m}^{-2}$ ash-free dry weight during March-October. Both predation pressure and growth of prey biomass was most intense from April to June. Lockwood (1972) calculated that 0.6 to $0.9 \mathrm{~g} \mathrm{~m}^{-2} \mathrm{dry}$ weight was available as food for 0 -group plaice in Filey Bay, Yorkshire (England). The rate at which the plaice population cropped the food in most cases was considerably less than $1 \%$ of the mean standing stock $\mathrm{d}^{-1}$ on any group of food items. In Kvambukten Bay, the yearly export of only 12 to $17 \%$ of the produced benthic biomass by the feeding activity of epibenthic predators of course is a tentative estimate but agrees with other studies from similar areas.

Assuming that epifauna consumption represents the only mortality of benthic infauna in Kvarnbukten Bay, we obtain an annual turnover of prey by dividing consumption by infauna mean standing stock, which yields a P/B ratio of 1.0. The total macro- and meiofauna production, however, should not be equated with the total output from the community, that is, the amount of food available for the shrimp and fish populations. The potential prey organisms display a vertical distribution within the substratum and the species which burrows deeply is not subjected to predation pressure. Besides the incapability of these predators to reach food organisms protected by the sediment cover, the low utilization of the potential prey species by the shrimp and fish populations can also be explained by the high $\mathrm{P} / \mathrm{B}$ ratio calculated for the benthic community. In addition, an undetermined amount of the benthic production is as well needed to satisfy the food requirements of predaceous infauna invertebrates. On the other hand, the predation impact from other mobile predator species will elevate the calculated exploitation rate. The common goby Pomatoschistus microps (Kroyer), the painted goby $P$. pictus (Malm), the two-spotted goby Gobiosculus flavescens (Fabricius) and the black goby Gobius niger L., although much less frequent, will contribute to the removal of benthic biomass from this habitat (Evans and Tallmark, in prep.). Caging experiments performed by Young et al. (1976) also emphasize the importance of predation by crabs. However, the predation impact by 0 -groups shore crab, Carcinus maenas (L.), on the meiofauna population in Kvarmbukten Bay, recalculated from Eriksson and Edlund (1977), amounted to $<1 \%$ of the annual infaunal production.

Availability of prey, food preferences and prey size are all significant factors in linking benthic predators to their prey (Levings, 1974). In shallow areas, the benthic community undergoes rapid changes. Variations in settling success make the supply of available food objects fairly unpredictable, favouring predator species with highly flexible feeding habits. The investigated epifauna predators were obvious generalists eating all prey they were able to overpower. Stomach contents closely reflected the relative abundance of available prey organisms. An increased range in foodsize utilization was observed with increasing size for all 3 epifauna species. However, though particle size generally increased with predator growth, large quan- 
tities of smaller prey such as copepods were still eaten by the larger specimens. This is probably due to the fact that food objects of optimal size become relatively rarer; smaller prey which occur in high densities therefore will still be consumed.

It seems reasonable that seasonal changes in food abundance will produce changes in the intensity of competition among epifauna species. The increasing overlap for the pair shrimp-plaice can be correlated to the increase in benthic abundance and biomass. However, overlapping exploitation patterns of food resources is just one aspect of conceivable interactions. If the full scope of competition is to be understood, other dimensions must be taken into consideration such as the time spent of foraging activity, depth distribution and habitat preferences (e.g. Werner, 1977). Bathymetrical distribution is of no relevance in this uniformly shallow area, and all 3 species are well adapted to the sandy habitat. In addition to the more conspicuous seasonal migration cycles, small temporal differences in activity rhythms may result in further segregation. Some differences in terms of daily foraging activity exist in the shrimp, and the 2 fish species. In non-tidal areas, the brown shrimp was nocturnal all the year round with the light-dark change acting as Zeitgeber (Hagerman, 1970; Eriksson et al., 1975). Juvenile plaice are mainly visually oriented feeders: their main feeding period is during daytime (Bregnballe, 1961; Verheijen and de Groot, 1967). In areas devoid of tidal oscillations, the feeding periodicity of the sand goby probably is correlated to light changes.

The significance of mobile predators in controlling distribution and abundance of benthic invertrebrates has been tested by experiments in intertidal and subtidal soft bottom environments (Blegvad, 1927; Woodin, 1974; Brunswig et al., 1976; Arntz, 1977; Reise, 1977a, b. 1978; Young et al., 1976; Virnstein, 1977; Berge, 1980; Berge and Hesthagen, 1981). Generally, densities of most species increased when protected from predators. Hence it appears that competitive forces working upon the infauna community are not very important; resources may not be limiting in littoral sand communities. Predation pressure by epibenthic predators and physical disturbances are thought to be the major extrinsic determinants keeping population levels below the carrying capacity of the environment (e.g. Muus, 1973; Rees et al., 1976, 1977).

However, the results of this investigation contradict the hypothesis that the epifauna regulates to a great extent their prey populations. At predation rates as low as those found in Kvarnbukten Bay it is unlikely that the shrimp and fish populations would seriously reduce or adversely affect benthic populations. This is in agreement with Berge and Hesthagen (1981), who showed experimentally that the common goby
Pomatoschistus microps did not crop infauna to any extent sufficient to alter infaunal composition or densities. McIntyre (1973) found no evidence that predation could depress meiofauna populations, and suggested that meiofauna may be largely at the top of a food chain. Most of the groups which form the diet of these shrimp and fish species have furthermore evolved a high fecundity and rapid reproductive cycle

Food deficiency may lead to niche segregation and food specialization by competing species. However, the shallow soft bottoms provide an abundant food supply that will neither limit the growth of these transient epibenthic exploiters nor produce severe competition between them, even though their diets are almost identical. Other dimensions of the niche, such as different times of foraging, may further diminish their interaction. Other factors are therefore likely to control the epibenthic populations. Steele and Edwards (1970) evaluated the relative importance of the different factors which might determine the populations of 0-group plaice at the end of the period which is spent close inshore. The settlement of newly metamorphosed plaice during April and May did not determine the population size in September. The existence of high mortality rates in other areas (Riley and Corlett, 1965; Macer, 1967) also indicate that predation may be a major controlling factor. Fonds (1973) estimated that normally $45 \%$ of the sand gobies from the Dutch Wadden Sea survived the first winter, $9 \%$ until the next October, and only 1 to $2 \%$ into a second breeding season at the age of 2 yr. Healy (1971) suggested heavy predation being the cause of the reduction in number of sand gobies during winter. Potential predators, such as larger fish, are also more numerous in the deeper areas to which the shrimp and fish migrate during winter. Thus, shallow areas will to some extent provide protection from larger predators (Evans and Tallmark, in prep.). The small size of juvenile flatfish and gobiid fish also incurs the risk of invertebrate predation. According to Muus (1967), predation on sand gobies by brown shrimp was observed, at least in captivity. My own observations in the field revealed that larger plaice as well as adult brown shrimp were able to catch and kill newly settled flatfish; this supports the opinion that predation may be major factor regulating epibenthic populations.

To sum up, the shrimp and fish populations inhabiting shallow soft bottoms are trophic generalists. Their food niches are almost identical but the abundant food supply will not produce severe competition between them. Predation both close inshore and during seasonal migrations offshore, may limit the populations inhabiting shallow water.

Acknowledgements. I am grateful to Professor S. Ulfstrand, Dr. B. Tallmark, and Dr. G. Gezelius for constructive comments. 


\section{L.TTERATURE CITED}

Andrássy, I. (1956). Die Rauminhalts- und Gewichtsbestimmung der Fadenwürmer (Nematoden). Acta Zool. Hung 2: $1-15$

Arntz, W. E. (1977). Results and problems of an 'unsuccessful' benthos cage predation experiment (Western Baltic). In: Keegan, B. F., O'Leidigh, Boaden, P. J. S. (eds.) Proceedings of 11 th European Marine Biology Symposium. Pergamon Press, Oxford, pp. 49-59

Banse, K., Mosher, S. (1980). Adult body mass and annual production/biomass relationships of field populations. Ecol. Monogr. 50: 353-379

Berge, J. A. (1980). Methods for biological monitoring: Biological interactions in communities of subtidal sediments. Helgoländer Meresunters. 33: 495-506

Berge, J. A., Hesthagen, I. H. (1981). Effects of epibenthic macropredators on community structure in an eutrophicated shallow water area, with special reference to food consumption by the common goby Pomatoschistus microps. Kieler Meeresforsch., Sonderh. 5: 462-470

Beukema, J. J. (1974). Seasonal changes in the biomass of the macro-benthos of a tidal flat area in the Dutch Wadden Sea. Neth. J. Sea Res. 8: 94-107

Beukema, J. J. (1976). Biomass and species richness of the macro-benthic animals living on the tidal flats of the Dutch Wadden Sea. Neth. J. Sea Res. 10: 236-261

Blegvad, H. (1927). Om fiskenes konsum av bunndyr. Et forsøg med oppvekst av bunndyr i kasser. Naturen 51: $22-29$

Bregnballe, F. (1961). Plaice and flounder as consumers of the microscopic bottom fauna. Meddr Danm. Fisk- og. Havunders. N. S. 3: 133-182

Brunswig, D., Arntz, W. E., Rumohr (1976). A tentative field experiment of population dynamics of macrobenthos in the Western Baltic. Kieler Meeresforsch. 3: 49-59

Buchanan, J, B., Warwick, R. M. (1974). An estimate of benthic macrofaunal production in the offshore mud of the Northumberland coast. J. mar, biol. Ass. U. K. 54: 197-222

Burke, M. V., Mann, K. H. (1974). Productivity and production: biomass ratios of bivalve and gastropod populations in an eastern Canadian estuary. J. Fish. Res. Bd Can. 31: $167-177$

Colman, J. A. (1970). On the efficiency of conversion of young plaice (Pleuronectes platessa). J. mar. biol. Ass. U. K. 50: $113-120$

Connell, J. H. (1961a). Effects of competition, predation by Thais lapillus, and other factors on natural populations of the barnacle Balanus balanoides. Ecol. Monogr. 31: $61-104$

Connell, J. H. (1961b). The influence of interspecific competition and other factors on the distribution of the barnacle Chthamalus stellatus. Ecology 42: 710-723

Connell, J. H. (1970). A predator-prey system in the marine intertidal region. 1. Balanus glandula and several predatory species of Thais. Ecol. Monogr. 40:49-78

Connell, J. H. (1972). Community interactions on marine rocky intertidal shores. Ann. Rev. Ecol. Syst. 3: 169-192

Connell, J. H. (1975). Some mechanisms producing structure in natural communities: a model and evidence from field experiments. In: Cody, L., Diamond, J. M. (eds.) Ecology and evolution of Communities. Belknap Press, Cambridge, pp. $460-490$

Dayton, P. K. (1971). Competition, disturbance, and community organization: the provision and subsequent utilization of space in a rocky intertidal community. Ecol. Monogr 41: $351-389$
Edwards, R., Steele, J. H. (1968). The ecology of 0-group plaice and common dabs at Loch Ewe. 1. Population and food. J. exp. mar. Biol. Ecol. 2: 215-238

Edwards, R., Steele, J. H. (1970). The ecology of 0-group plaice and common dabs at Loch Ewe. 1. Population and food. J. exp. mar. Biol. Ecol. 2: 215-238

Eriksson, S., Evans, S., Tallmark, B. (1975). On the coexistence of scavengers on shallow, sandy bottoms in Gullmar Fjord (Sweden): activity patterns and feeding ability. Zoon 3: 121-124

Eriksson, S., Edlund, A-M. (1977). On the ecological energetics of 0 -group Carcinus maenas (L.) from a shallow sandy bottom in Gullmar Fjord, Sweden. J. exp. mar. Biol. Ecol. 30: $233-248$

Evans, S., Tallmark, B. (1975). Abiotic factors on a shallow, sandy bottom in Gullmar Fjord (Sweden). Zoon 3: 61-64

Evans, S., Tallmark, B. (1976). Distribution and size frequency of bivalve molluscs on a shallow, sandy bottom in Gullmar Fjord (Sweden). Zoon 4: 47-52

Evans, S., Tallmark, B. (1977). Growth and biomass of bivalve molluscs on a shallow, sandy bottom in Gullmar Fjord (Sweden). Zoon 5: 33-38

Evans, S., Tallmark, B. (1979). A modified drop-net method for sampling mobile epifauna on marine, shallow, sandy bottoms and its application in a Swedish Fjord. Holarct. Ecol. 2: 58-64

Fonds, M. (1973). Sand gobies in the Dutch Wadden Sea (Pomatoschistus, Gobiidae, Pisces). Neth. J. Sea Res. 6: $417-478$

Gerlach, S. A. (1971). On the importance of marine meiofauna for benthos communities. Oecologia 6: 176-190

Hagerman, L. (1970). Locomotory activity patterns of Crangon vulgaris (Fabricius) (Crustacea, Natantia). Ophelia 8: 255-266

Healy, M. C. (1971). The distribution and abundance of sand gobies, Gobius minutus, in the Ythan estuary. J. Zool., Lond. 163: 177-229

Healy, M. C. (1972). Bioenergetics of a sand goby (Gobius minutus) population. J. Fish. Res. Bd Can. 29: 187-194

Heip, C., Vranken, G (1977). Production of the ostracod Cyprides torosa (Jones 1850). Abstract of poster demonstration. Third International Meiofauna Conference, Hamburg

Horn, H. S. (1966). Measurement of 'overlap' in comparative ecological studies. Am. Nat. 100: 419-424

Kuipers, B. R. (1977). On the ecology of juvenile plaice on a tidal flat in the Waden Sea. Neth. J. Sea Res. 11: 56-91

Lasker, R., Wells, J. B., McIntyre, A. D. (1970). Growth, reproduction, respiration and carbon utilization of the sanddwelling harpactcoid copepod, Asellopsis intermedia. J. mar. biol. Ass. U. K. 50: 147-160

Levings, C. D. (1974). Seasonal changes in feeding and particle selection by winter flounder (Pseudopleuronectes americanus). Trans. Am. Fish. Soc. 4: 828-832

Levins, R. (1968). Evolution in changing environments, Princeton University Press, Princeton

Levinton, J. S., Baumbach, R. K. (1975). A comparative study of Silurian and Recent deposit-feeding bivalve communities. Paleobiology 1: 97-124

Lockwood, S. J. (1972). An ecological study of an 0-group plaice (Pleuronectes platessa L.) population. Filey Bay, Yorkshire. Ph. D. thesis, University of East Anglia, England

MacArthur, R., Levins, R. (1967). The limiting similarity, convergence, and divergence of coexisting species. Am. Nat. 101: $377-385$

McIntyre, A. D. (1970). The range of biomass in intertidal 
sand, with special reference to the bivalve Tellina tenuis. J. mar, biol. Ass. U. K. 50: 561-575

Mclntyre, A. D. (1973). The meiofauna of a flatfish nursery ground. J. mar. biol. Ass. U. K. 53: 93-118

Meixner, R. (1968). Experimentelle Untersuchungen zur Biologie der Nordseegarnele Crangon crangon (L.). Dissertation, Universität Hamburg

Muus, B. J. (1967). The fauna of Danish estuaries and lagoons. Distribution and ecology of dominating species in the shallow reaches of the mesohaline zone. Meddr Danm. Fisk.- og Havunders. 5: 1-316

Muus, K. (1973). Settling, growth and mortality of young bivalves in the Oresund. Ophelia 12: 79-116

Muiller, A. (1969). Körpergewicht und Gewichtszunahme junger Plattfische in Nord- und Ostsee. Ber. dt. wiss. Kommn. Meeresforsch. 20: 112-128

Olsson, I. (1975). On methods concerning marine benthic meiofauna. Zoon 3: 49-60

Paine, R. T. (1974). Intertidal community structure. Experimental studies on the relationship between a dominant competitor and its principal predator. Oecologia 15: 93-120

Peterson, C. H. (1977). Competitive organization of the softbottom macrobenthic communities of southern California lagoons. Mar. Biol. 43: 343-359

Peterson, C. H., Andre, S. V. (1980). An experimental analysis of interspecific competition among marine filter feeders in a soft-sediment environment. Ecology 61: 129-139

Rees, E. I. S., Eagle, R. A., Walker, A. J. M. (1976). Trophic and other influences on macrobenthos population fluctuations in Liverpool Bay. In: Persoone, G., Jaspers, E. (eds.) Proceedings of 10th European Marine Biology Symposium Universa Press, Wetteren, pp. 589-599

Rees, E. Y. S., Nicholaidou, A., Laskaridou, P. (1977). The effects of storms and the dynamics of shallow water benthic associations. In: Keegan, B. F., O'Leidigh, P. Boaden, P. J. S. (eds.) Proceedings of 11th European Marine Biology Symposium. Pergamon Press, Oxford, pp
$465-474$

Reise, K. (1977a). Predation pressure and community structure of an intertidal soft-bottom fauna. Proceedings of 11 th European Marine Biology Symposium. Pergamon Press, Oxford, pp. 513-519

Reise, K. (1977b). Predator experiments in an intertidal mud flat. Helgoländer wiss. Meeresunters. 30: 263-271

Reise, K. (1978). Experiments on epibenthic predation in the Wadden Sea. Helgoländer wiss. Meeresunters. 31: 55-101

Riley, J. D., Corlett, J. (1965). The numbers of 0-group plaice in Port Erin Bay. Rep. Mar. biol. Stn Port Erin 78: 51-56

Snedecor, G. W., Cochran, W. G. (1967). Statistical methods, 6th ed. Iowa State University Press, lowa, USA

Verheijen, F. J., de Groot, S. J. (1967). Diurnal activity pattern of plaice and flounder (Pleuronectidae) in aquaria. Neth. J. Sea Res. 3: 383-390

Virnstein, R. W. (1977). The importance of predation by crabs and fishes on benthic infauna in Cheaspeake Bay. Ecology 58: $1199-1217$

Warwick, R. M., Price, R. (1975). Macrofauna production in an estuarine mud-flat. J. mar. biol. Ass. U. K. 55: 1-18

Warwick, R. M., Joint, I. R., Radford, P. J. (1979). Secondary production of the benthos in an estuarine environment. In: Jefferies, R. L., Davy, A. (eds.) Proceedings of the First European Ecological Symposium: ecological processes in coastal environments. Blackwell Scientific Publications, Oxford, pp. 429-450

Werner, E. E. (1977). Species packing and niche complementarity in three sunfishes. Am. Nat. 111: 553-578

Wieser, W. (1960). Benthic studies in Buzzards Bay. 2. The meiofauna. Limnol. Oceanogr. 5: 121-137

Woodin, S. A. (1974). Polychaete abundance patterns in a marine soft-sediment environment: the importance of biological interactions. Ecol. Monogr 44: 171-187

Young, D. K., Buzas, M. A., Young, M. W. (1976), Species densities of macrobenthos associated with seagrass: a field experimental study of predation. J. mar. Res. 34: $577-592$ 